\title{
ADVENTITIOUS BUD REGENERATION FROM THE STIGMA OF Sinapis alba L.
}

\author{
Lukasz Zarychta, Elżbieta Zenkteler \\ Department of General Botany, Institute of Experimental Biology, A. Mickiewicz University, \\ 61-614 Poznań, Umultowska 89, Poland \\ e-mail: Elzbieta.Zenkler@amu.edu.pl
}

Received: 9.04.2010

\begin{abstract}
Stigmas isolated from flower buds of 'Nakielska' variety of Sinapis alba were used to develop a micropropagation method suitable for breeding of new cultivars. The origin of adventitious bud regeneration was studied on MS medium, under stimulation by bezylaminopurine (BAP) in combination with 2,4-D - dichlorophenoxyacetic acid (2,4-D). Histological analysis showed the structure of Sinapis stigma (composed from four types of tissue: papillae, transmitting tissue, parenchyma and vascular bundles) and revealed that numerous meristematic centers developed from parenchyma cells in close vicinity of vascular bundles. Buds very quickly appeared on the surface of initial explants and later formed multiplantlets that were easily rooted in the soil.
\end{abstract}

Key words: Sinapis alba L. (Brassica hirta), white mustard, stigma-culture, adventitious bud regeneration, plantlet development

\section{INTRODUCTION}

Sinapis alba L. belongs to the family Brassicaceae and is widely distributed as a crop species in the temperate regions of the world. S. alba var. 'Nakielska' $(2 n=24)$ is a variety of white mustard common in Poland and known for its commercial importance and medicinal properties. Because of the large demand for new valuable varieties of white mustard, a large scale breeding program has been launched for which the traditional method of propagation is too slow. Therefore methods of micropropagation of $S$. alba from different explants have been developed e.g. using anthers (K $1 \mathrm{i}$ m a s z e w s k a and K e 11 e r 1983); cotyledons (J a i n et al. 1989) or pistils and stamens (Z a r y c h t a et al. 2007). Stigmatic surface of Sinapis has been classified as 'dry' based on the absence of exudates secretion from papillae (an outgrowth of epidermal cells). In Brassicaceae the stigma as an area of pollen adhesion, recognition and hydration is been very rich in signaling molecules, especially the small (6-7 kD) stigmatic cysteine-rich proteins, glycoproteins and defensins (showing antimicrobial activity) (M o $11 \mathrm{e} \mathrm{t}$ et al. 2007). Transmitting tissue lying beneath of the papillae layer in the 'solid' style also contain numerous arabinogalactan (AGPs) and proline-rich proteins (PRPs). The two active layers together with ground parenchyma and vascular bundles constituted the initial stigmatic explants. The aim of the paper was to determine which tissue of the stigmatic explants of $S$. alba gave origin to regeneration of adventitious buds in tissue culture.

\section{MATERIALS AND METHODS}

\section{In vitro culture of stigmatic explants}

Closed flower buds to be used as explant sources were collected from plants growing in the field. After a quick dip in $70 \%$ ethanol (v/v) for $3 \mathrm{sec}$. flowers were disinfected with $2 \%$ solution of sodium hypochlorite $(\mathrm{v} / \mathrm{m})$ for $3 \mathrm{~min}$ and thoroughly washed with sterile distilled water. Pieces of stigmas were excised from isolated pistils (Figs 1-3) and placed on the MS medium (M u r a s h i g e and S k o o g , 1962), supplemented with $3 \mathrm{mg} \cdot \mathrm{l}^{-1} \mathrm{BAP}$ in combination with $1.6 \mathrm{mg} \cdot \mathrm{l}^{-1} 2,4-\mathrm{D}$ following the formulation most suitable for bud induction ( $\mathrm{Z}$ a r y c h t a et al. 2007). The medium contained $3.0 \%(\mathrm{w} / \mathrm{v})$ sucrose, $0.8 \%(\mathrm{w} / \mathrm{v})$ Difco agar and the $\mathrm{pH}$ value was adjusted to 5.8 before autoclaving at $120^{\circ} \mathrm{C}$ for $20 \mathrm{~min}$. Cultures of stigmas were incubated at $20 \pm 23^{\circ} \mathrm{C}$ in a culture room under 20 $\mu \mathrm{E} \mathrm{m} \mathrm{m}^{-2} \mathrm{~s}^{-1}$ continuous light. In vitro developed shoots were transferred to MS medium containing $1 \mathrm{mg} \cdot \mathrm{l}^{-1}$ IAA for root induction. Before planting plantlets into soil they were acclimated on growth regulator-free medium. 

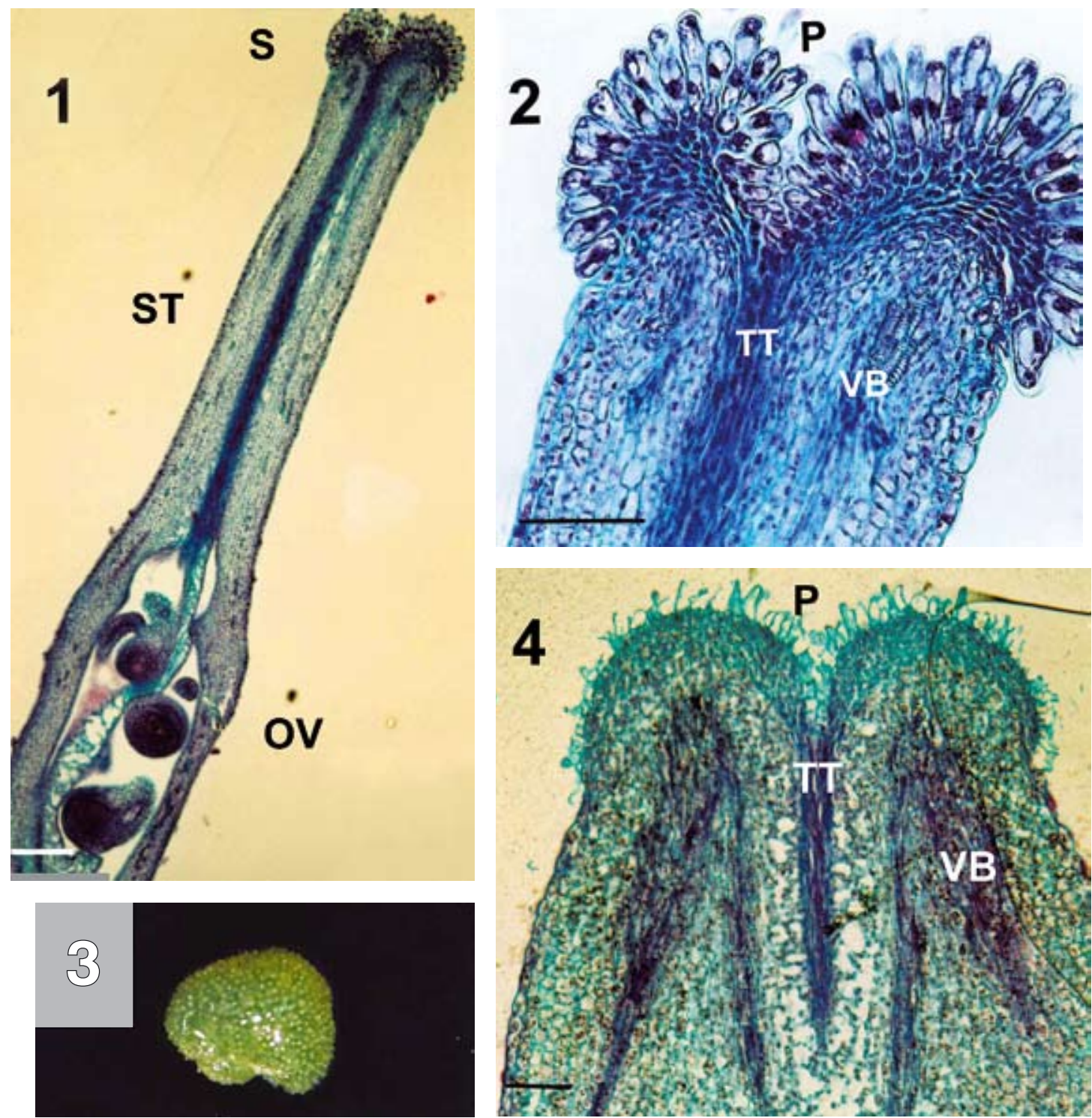

Figs 1-4. Pistil and stigma of Sinapis alba. Fig. 1. Longitudinal section of white mustard pistil at anthesis, $\mathbf{S}-$ stigma, ST - style, $\mathbf{O V}$ - ovary with ovules. Fig. 2. Magnification of papillae (P) at the top of the stigma, VB - vascular bundles, TT transmitting tissue. Fig. 3. Top view on the surface of isolated stigma (initial explant). Fig. 4. Longitudinal section of isolated stigma after 7 days on MS medium containing $1.6 \mathrm{mg} \cdot \mathrm{l}^{-1} 2,4-\mathrm{D}$ and $3 \mathrm{mg} \cdot \mathrm{l}^{-1} \mathrm{BAP}$. Bars $-100 \mu \mathrm{m}$

\section{Histological analysis}

For analysis in the light microscope stigmas were fixed in FAA, dehydrated in the ethanol-xylene series and embedded in paraffin. Serial 10-12 micron transverse and tangential sections were cut in a rotary microtome and stained with safranin-fast green according to the standard light microscopy method.

\section{RESULTS AND DISCUSSION}

\section{Histological analysis}

The stigmatic papillae of Sinapis alba are unicellular, clavate and densely cytoplasmic. During stigma maturation, at first, richly cytoplasmic papillae become vacuolated and enlarged. Next, endomitotic phase begins and their nuclei reach tetraploid or even octaploid state. The cells with prominent, well stained nuclei have a thickened wall covered with a pellicle (Fig. 2). The transmitting tissue consists of compactly arranged, elongated, uninucleate cells. The tissue is restricted to an area adjoining the vascular bundles. After maturation the tissue breaks down lysogenously. Parenchyma tissue contains medium sized, vacuolated cells, which soon start to divide and proliferate callus. A detailed study of the morphology and anatomy of the stigma in its developmental stages was helpful during tissue culture of Sinapis. 

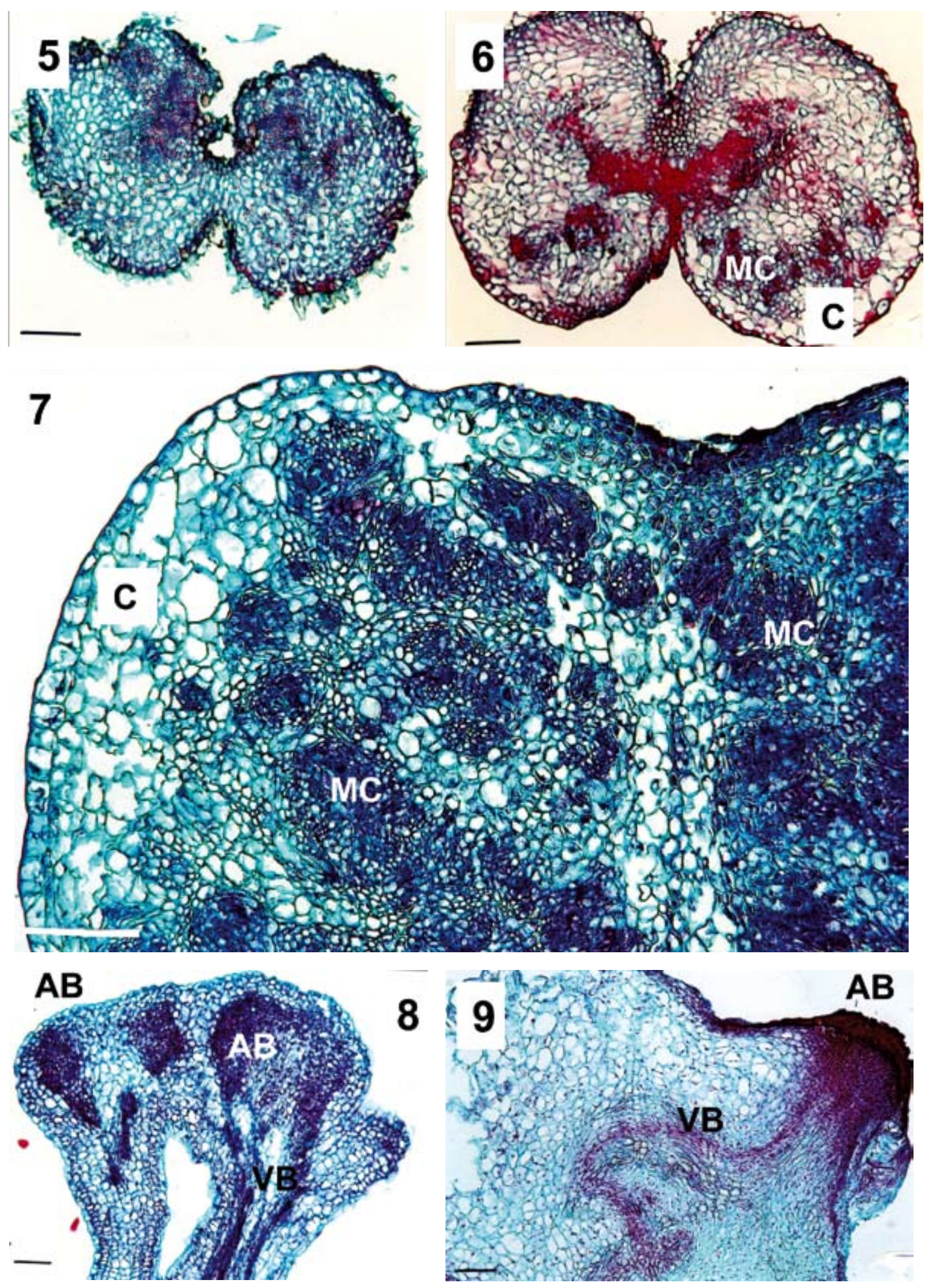

Figs 5-6. Transverse sections of stigmas after 7 and 14 days under growth regulators stimulation; callus (C) proliferation from ground parenchyma. Fig. 7. Differentiation of the meristematic centers (MC) after 22 days on the MS medium. Figs 8-9. Longitudinal sections of stigmas after 35 days on the MS medium; development of numerous adventitious buds. (AB), conneected to vascular bundles (VB) Bars $-100 \mu \mathrm{m}$. 

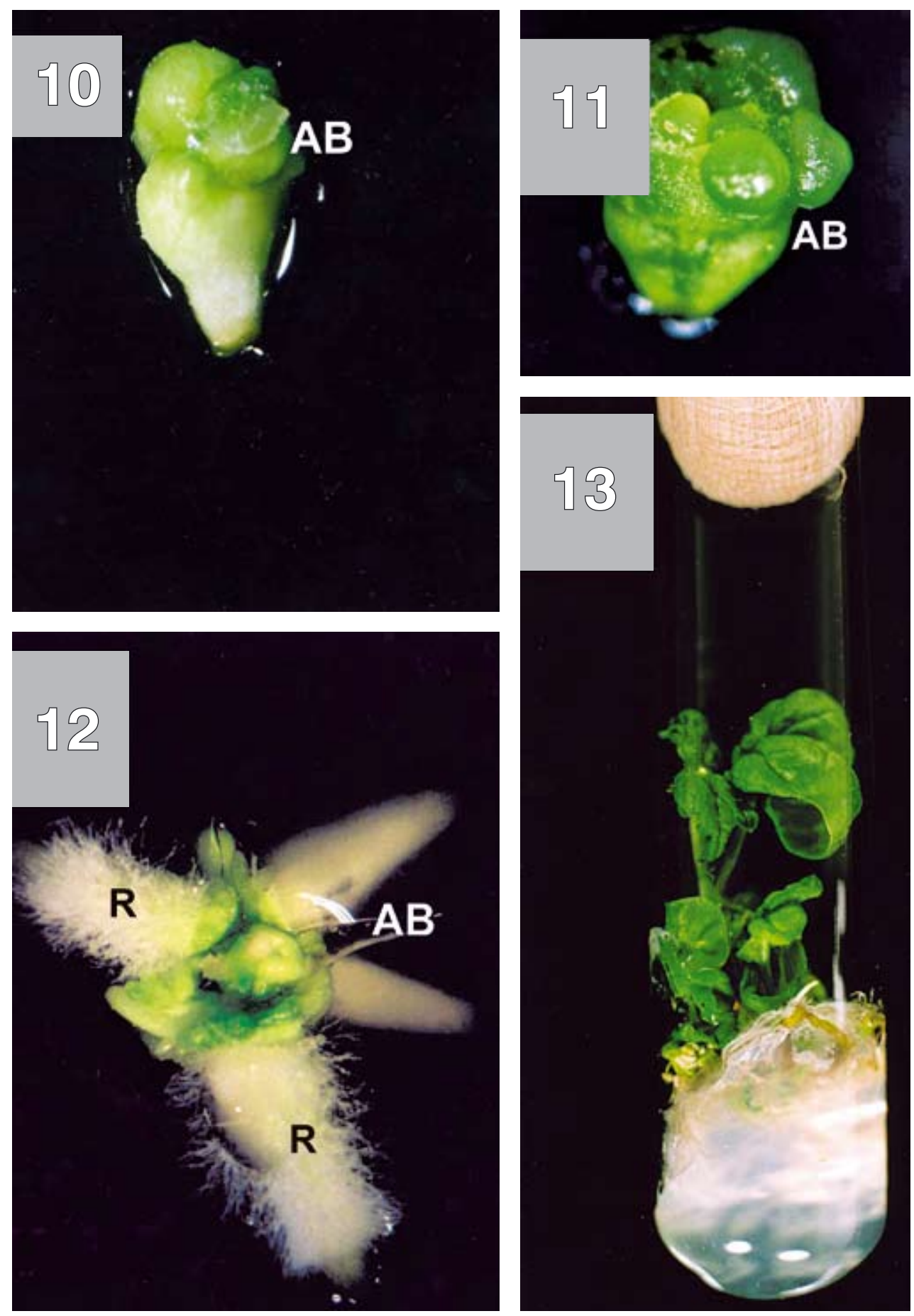

Figs 10-11. Adventitious bud regeneration from the stigma-explants after 40 days on MS medium containing $1.6 \mathrm{mg} \times \mathrm{l}^{-1} 2,4-\mathrm{D}$ and $3 \mathrm{mg} \times \mathrm{l}^{-1}$ BAP. Fig. 12. Root development after transfer of plantlets onto MS medium supplemented with $1 \mathrm{mg} \times \mathrm{l}^{-1} \mathrm{IAA}$. (Magn. 10x) Fig. 13. Plantlet of Sinapis alba regenerated from a stigmatic explant

\section{In vitro culture of stigmatic explants}

The papillae at the top of the surface of isolated stigma started to loose their turgor and soon collapsed. Longitudinal and transverse sections of stigmas after 7 days on the MS medium revealed that the reduction in size and number of papillae proceeded very quickly
(Figs 4-6). Neither polyploidy nor the wall thicknes disturb the process of their disintegration. Also the single stranded and multilayered transmitting tissue (at the center of Figs 6-7) did not participate in dedifferentiation of stigmatic cells. Under growth regulator stimulation (1.6 mg $\times 1^{-1} 2,4-\mathrm{D}$ and $3 \mathrm{mg} \times \mathrm{l}^{-1} \mathrm{BAP}$ on MS medium), callus proliferation appeared from 
the ground parenchyma (Figs 6-7). Differentiation of meristematic centers took place in close vicinity of vascular bundles after 22 days of the culture (Figs 7-9). After about 30-40 days on the MS medium, numerous adventitious buds protruded out of the stigma surface (Figs 10-11). Root development started after explants were transferred onto medium supplemented with $1 \mathrm{mg} \times \mathrm{l}^{-1}$ IAA (Fig. 12). Multiplantlets of Sinapis alba were ready to be planted into soil at 2 months after stigma isolation (Fig. 13).

Stigmas in plant micropropagation are used rather seldom. Among the few published examples are broccoli stigmas (Z e n k te ler et al. 2006). We followed that experiment to determine if the most active tissues of stigma (i.e. papillae and transmitting tissue) participated or not in the organogenesis. This paper reports for the first time on the use of stigmas of Sinapis as effective explants for micropropagation.

To sum up: in the near future, a great deal of effort will be required to obtain new, economically viable varieties of mustard contaning low levels of glycosylanes or erucic acid. Because of the demand for such varieties and the very slow traditional method of propagation, it is important to develop an efficient micropropagation technique to rapidly disseminate clones once they are identified. In the present work, suitability of the detached stigma of white mustard as an experimental system (via organogenesis) was confirmed.

\section{REFERENCES}

Jain R.K., Brune U., Friedt W., 1989. Plant regeneration from in vitro cultures of cotyledon and another explants of Sinapis alba; its implication on breeding of crucifers. Euphytica, 43: 153-163.

Klimaszewska K., Keller W.A., 1983. The production of haploids from Brassica hirta Moench (Sinapis alba L.) anther culture. Z. Pflanzenphysiol. 109: 235-241.
Mollet J-C., Faugeron C., Morvan H., 2007. Cell adhesion, separation and guidance in compatible plant reproduction. [In]: J.A. Roberts, Z. Gonzalez-Carranza (eds), Plant cell separation and adhesion, 25: 69-90, Blackwell Publ.

Murashige T., Skoog F., 1962. A revised medium for rapid growth and bioassays with tobacco tissue culture. Plant Physiol. 15: 473-497.

Zenkteler M., Zenkteler E., Dostatnia I., 2006. Somatic embryogenesis from broccoli stigmas [In:] tissue culture. Acta Biol. Crac. Ser. B. 48 (2): 121-125.

Zarychta Ł., Zenkteler M., Zenkteler E., 2007. Organogenesis from flower elements of white mustard (Sinapis alba L.). Zesz. Probl. Post. Nauk Roln. 523: 247-252.

\section{Regeneracja pąków przybyszowych ze znamion Sinapis alba $\mathrm{L}$.}

\section{Streszczenie}

Znamiona słupków izolowanych z pąków kwiatowych gorczycy (Sinapis alba) odmiany 'Nakielska' wykorzystano przy opracowaniu metody mikrorozmnażania, przydatnej do hodowli nowych odmian. Analizowano pochodzenie pąków przybyszowych regenerujących na pożywce MS pod wpływem stymulacji bezylaminopuryną - BAP i kwasem 2,4- naftoksyoctowym 2,4-D. Analiza histologiczna wykazała, że znamiona Sinapis zawierały cztery typy tkanek (epidermalne papille, tkankę transmisyjną, miękisz podstawowy i elementy wiązki przewodzącej) oraz ujawniła, że liczne centra merystematyczne rozwinęły się z odróżnicowanych komórek parenchymy w bezpośrednim sąsiedztwie wiązek przewodzących. Pąki przybyszowe bardzo szybko rosły, ukazując się na powierzchni eksplantatów po 45 dniach kultury. Struktury te rozwinęły się w łatwo ukorzeniające się, silne wieloroślinki. 
